\title{
Chosen Tax-Related and Economic Aspects of Choosing the Method of Equity Financing in Relation to Thin Capitalisation in the Countries of OECD
}

Dominik Gajewski ${ }^{1}$

ABSTRACT

KEY WORDS:

JEL Classification:

\begin{abstract}
The present publication is concerned with the process of thin capitalisation in the countries of OECD. Two methods for financing companies are discerned in relation to this phenomenon, i.e. debt and equity financing. The tax-related consequences of the method of equity financing of companies are assessed against thin capitalisation. It is the very tax policy of companies that has a direct influence on the economic consequences of the functioning of these companies. The process of taxation of the phenomenon of thin capitalisation may be highly varied depending on the adopted method. Tax-related consequences demonstrate how complicated this process is irrespective of the country in which it takes place. The issue is even more complicated in the case of taxation of this process in companies conducting cross-border activity.
\end{abstract}

corporate income tax, thin capitalisation, OECD

1 University of Finance and Management in Warsaw, POLAND

\section{Introduction}

The present paper is concerned with the presentation of the phenomenon of thin capitalisation in the context of the economic consequences of the functioning of companies in the countries of OECD. Thin capitalisation is a process which is strictly economic in nature. The key aspects required to assess the process of thin capitalisation are its tax-related consequences. In fact, commencement of this process in companies is determined by the tax-related consequences. As Clausing (2007) states it, "it is noteworthy that highly developed countries of OECD introduce tax rates which maximise income derived from income tax". (p. 118). This

Corespondence concerning to this article should be addressed to: d.gajewski@op.pl burden is borne mainly by economic entities having a business status of a company.

The way (or method) of carrying out the process of thin capitalisation constitutes a factor which must inevitably be taken into account in the assessment of this process. Companies may chose from two methods: debt or equity financing. However, in order to chose the appropriate and the most suitable method, it is necessary and essential to define the tax-related consequences of this method. This is because companies should bear in mind that no general rule exists and each of them should asses their situation individually taking into account the very tax-related consequences. Moreover, it is important that the issue of thin capitalisation is presented in the light of the standards of the OECD Model Tax Convention which is applicable for the EU countries. The present paper proposes that 

meeting (i.e. the General Meeting of Shareholders) by way of a resolution (Helminen, 1999, p. 232).

It is noteworthy that both the dividends and other income derived from a share in the profit of a company are expenses incurred by the distributing company which are not considered tax deductibles in the light of income tax acts. Since there is no possibility to deduct such expenses as tax deductibles, the phenomenon of - economic double taxation - is observed. Thus the method of equity financing becomes less appealing if its tax-related aspects are considered.

The phenomenon of economic double taxation constitutes the most significant consequence of choosing the method of equity financing. Since the tax-related consequences are highly influential, the phenomenon of economic double taxation makes this method of financing less appealing for companies. Double taxation consists in taxation of a company's profit two times; first, the company pays income tax on the profit and; second, the shareholders pay tax on their dividends. This means that the same object, i.e. an economic phenomenon, is taxed twice only two different entities pay the tax on it (Fiszer, 1990, p. 76; Głuchowski, 1983, p. 59). The fact that both the company and the shareholders are taxable persons and the fact that tax is imposed on both income and capital constitute direct causes of the phenomenon of double taxation (Komar, 1996, p. 55; Helminen, 1999, p. 232). This phenomenon does not emerge when debt financing is employed because income calculated by way of deducting interest from a company's revenue as tax deductibles does not bear the burden of tax on the company's income.

Depending on whether the shareholder of the company distributing dividends is another company or a natural person, the phenomenon of economic double taxation may be considered from two different perspectives. Double taxation of companies acting as shareholders is a major impediment to building organizational and capital relationships between holding companies and subsidiaries within Holdings (Gajewski, 2004, p. 97).

However, it is possible for the holding company to benefit from equity financing. If the method of equity financing is employed and the holding company contributes to the majority of the subsidiary's share capital, the dividends paid to the holding company will be treated by the OECD member countries in a privileged manner (OECD, 1987, p. 34; Portner, 1996, p. 266). This is because these countries make effort to alleviate the problem of economic double taxation by allowing deduction of the tax on profit allocated for distribution paid by the subsidiary from the tax payable on income that the holding company derives from dividend or exempting dividend from tax in the case of the holding company (Poterba, 2004, p. 551).

Tax credit, on the other hand, serves to deduct the tax on profit allocated for distribution paid by the subsidiary. Tax credit is granted to the holding company both on the basis of internal legal regulations and bilateral agreements concerning avoiding double taxation (it is the so called indirect credit). Participation exemption also has a similar application as it serves tax exemption of dividends paid by subsidiaries to the holding company (Dziedzic-Wach \& Michalszczyn, 1997, p. 2).

Some OECD member countries (such as Austria, the Netherlands, and Luxemburg) have introduced tax solutions ensuring full integration of taxes imposed on the profits of a company distributing dividends. The system comes down to eliminating income derived from dividends received by the holding company by way of tax exemption. In order for the system to be implemented, it is necessary for the holding company to provide a certain contribution to the subsidiary's capital of at least $25 \%$ of its nominal value and to hold the shares for a certain period of time (Vogel, 1997, p. 710; Sasseville, 1995, p. 32).

Eliminating double taxation of dividends is much more complicated in the case of natural persons acting as shareholders. The difficulty that lies at the heart of the problem is that, in most OECD member countries, dividend is counted together with income arising from other sources and is taxed with a tax rate relevant for the total income of the taxable person. Statutory regulations of only a few countries, such as Poland, differ in this matter (Aleksandrowicz, Fiszer \& Jędrzejewski, 1995, p. 9). The income derived from a share in a company's profit and income derived from other sources of revenue are not aggregated in these countries. Income arising from a share in a company's profit is taxed on the basis of its gross value with a separate tax rate of corporate income tax in line with the act of 26 July 1991 on corporate income tax (Journal of Laws of 2010 No. 51 item 307 as amended). 


\section{Economic consequences of employing the method of equity financing}

In some OECD countries, the method of equity financing is subject to capital tax or tax on the nominal value of capital, capital transfer tax or the tax on legal and civil transactions whose object of taxation is the performance of a legal transaction consisting in contributing to a company's capital in exchange for receiving the right to share in its profit (Białobrzeski, 1998). Such tax types are operative in most OECD member countries, inter alia: Australia, Belgium, France, Ireland, Spain, the Netherlands, Japan, Luxemburg, Poland, and Switzerland. Shareholders' contributions to the capital are neutral from the point of view of taxation in other countries, apart from certain taxes on legal and civil transactions (Doernberg, 1995, p. 12).

An interesting phenomenon related to taxation is that some countries (Germany, Switzerland, and Italy) introduced taxes whose object of taxation is the value of capital (i.e. the net worth tax) and it is imposed on the value of shares held by natural persons (Hamaekers et al., 2006, p. 134; Sieker, 1997, p. 222).

Bearing in mind the abovementioned factors, the shareholders planning to adopt the method of equity financing must take into account these additional tax burdens - related to taxation of a company's profit and income arising from a share in this profit. Besides double taxation of a company's profit in the economic sense, the ban on deducting dividends as tax deductibles by companies constitutes another tax-related difference between the methods of debt and equity financing. It is not surprising that countries which introduced the taxes mentioned above (the capital tax and the net worth tax) perceive thin capitalization and consequently introduce legal regulations limiting this phenomenon (Hayder, 2000, p. 41).

In conclusion, when considering choosing the method of equity financing in the light of tax law, the following factors must be born in mind:

- as a rule, dividends are not considered tax deductibles for a company distributing them and thus may not be deducted from the revenue of this company;

- statutory regulations of some OECD member countries contain such rules concerning taxation of companies' profits and dividends - as part of the profit - that take into account the phenomenon of thin capitalization in the economic sense;

share capital may be subject to capital tax; net worth tax may be imposed on shareholders; the distributed dividend may be taxed with the so called withholding tax which is calculated, collected and paid by the distributing company; if the receiver of the dividend is a resident of a different country than the country in which the company has its registered office, agreements concerning double taxation may stipulate reduction of the rate of the withholding tax; such agreements are based on Article 10 of the OECD Model Agreement (Fuest \& Hemmelgarn, 2005, p. 512).

The phenomenon of economic double taxation of income derived from dividend is the most serious and the most widespread factor causing companies to refrain from adopting the method of equity financing. Shareholders are forced to search for other alternative methods of financing. Moreover, the way of separation of the jurisdiction of the country at source and the jurisdiction of the country of residence is also an important matter stipulated in bilateral agreements based on the OECD Model Agreement concerning avoiding double taxation. In accordance with the OECD Model Agreement, both countries of the parties entering an agreement may impose tax on dividends, however, the right to impose tax on income derived from this source is limited in case of the country at source and the country of residence is obliged to adopt a relevant method of avoiding double taxation (OECD, 1992, p. 108). Nevertheless, practice unfortunately differs among OECD member countries. On the one hand, if the country at source relinquishes the right to impose tax on the income derived from dividends, foreign investors will be encouraged, on the other hand, this will cause loss to the budget since less money will be collected as income tax (Becker \& Fuest, 2011).

From the point of view of taxpayers, the method of equity financing is definitely much less appealing for companies than the method of debt financing. In the case of thin capitalization, the choice of a method of financing is dependent on the need to optimize taxation in companies. The method of debt financing is predominantly more appealing for the shareholders who employ it (Overesch \& Wamser, 2010). The benefit brought about by this method is especially perceivable in comparison to the method of equity financing. 
The difference may be recognized on both the domestic level, i.e. when the shareholder and the financed company are residents of the same country but also on the international level when these entities are residents of different countries (Valchy, 2008, p. 660).

Legal regulations concerning taxation of income derived from interest paid to shareholders who have chosen the method of debt financing allow to classify the expenses incurred by the company with respect to this operation as tax deductibles. Consequently, the income of the company which is subject to taxation is lowered; such income is considered the positive result of subtraction of tax deductibles from the revenue.

Differences related to taxation with respect to the chosen method of financing are more visible in the case of cross-border settlements when the financing entity is a shareholder residing or having a registered office on a territory of a different country than the one in which the financed company has its registered office. In this case, the rules governing taxation of the income discussed in this paper may be altered on the basis of stipulations provided in bilateral agreements concerning prevention and avoidance of double taxation (Lipowski, 1999, p. 16).

The fact that the method of debt financing is frequently adopted by companies in practice point to a conclusion that tax-related aspects constitute the main reasons behind choosing the method of debt financing. As a result, fiscal authorities and the legislature itself undertake strenuous action with respect to this financing solution. Such strenuous reaction arises due to the fact that the basic function of tax is being a public levy serving, first of all, as a source for covering the state's demand for public income and, second of all, as means of exerting a certain influence on the economic behaviour of taxable persons, which is the so called non-fiscal function of taxes (Gomułowicz \& Małecki, 2002; Gajl, 1992).

As Laconick and O'Sullivan (2000) rightly observe, the evaluation of the tax-related and economic consequences of the method of equity financing demonstrates their influence on the policy of American and European companies manifesting itself in the growing number of companies seeking external financing sources on the capital market or getting into debts granted by banks. According to Palpaceur (2008) such policy leads to an increase in the importance of banks and other financial institutions among shareholders institutional investors - and the increased influence of these entities over the strategy of companies forming corporations. (p. 1120).

\section{Conclusions}

Bearing in mind the abovementioned factors, it is possible to draw a conclusion that although the method of equity financing is "safer" for companies, since it is less likely to be challenged by tax authorities, it is less beneficial than the method of debt financing due to the tax-related advantages brought by it. Undoubtedly, the adverse phenomenon related to the method of equity financing is economic double taxation. This phenomenon causes the costs of adopting this method to increase, which, from the economic perspective, has direct influence over the decisions made by companies.

As Devereux, Lockwood, and Redoano (2008) justly state the phenomenon of economic double taxation will influence the process of harmonization of the tax policies of OECD member countries concerning the corporate income tax, especially at the time of crisis. (p. 1220).

Furthermore, it may be explicitly stated that a company must carry out a realistic assessment of the tax-related consequences arising from the chosen method of financing before it chooses the method of thin capitalization. This is because these tax-related consequences are one of be basic factors influencing an economic position of a company. Since tax-related consequences of the method of equity financing are much less beneficial for a company than those of the method of debt financing, it may be stated that this phenomenon has direct influence on the economic consequences. It is not surprising that due to taking the very economic point of view any entity would choose a less burdensome tax policy allowing it to achieve its economic goals.

\section{References}

Aleksandrowicz, M., Fiszer J. \& Jędrzejewski S. (1995). Opodatkowanie dywidend [Taxation of Dividends], Przegląd Podatkowy, 3, 9-10.

Bandrzewski, K. (1996). Prawo do udziałów w zysku rocznym oraz prawo do dywidendy przysługujące akcjonariuszom w spółce akcyjnej [The Right to Share in the Annual Profit and the 
Right to Dividend of Shareholders in a JointStock Company]. Przegląd Ustawodawstwa Gospodarczego, 7, 7-9.

Becker, J., Fuest, C. (2011). Optimal tax policy when firms are internationally mobile. International Tax and Public Finance, 18, (5), 580-604.

Białobrzeski, J. (1998). Vademecum Podatnika: Międzynarodowe Prawo Podatkowe. Komentarz [The Taxpayer Vademecum: International Tax Law]. Warszawa: Difin.

Brzeziński, B., Hayder, R. (1997). Niedostateczna kapitalizacja spółek kapitałowych [Thin Capitalisation of Companies]. Monitor Podatkowy, 2, 32-35.

Clausing, K. (2007). Corporate Tax Revenues in OECD Countries. International Tax and Public Finance, 14, 115-133.

Devereux, M. P., Lockwood, B. \& Redoano, M. (2008). Do Countries Compete over Corporate Tax Rates. Journal of Public Economics, 92 (5-6), 1210-1235.

Doernberg, R. L. (1995). Amending the OECD Model Treaty and Commentary Response to Corporate Tax Integration. In: International taxation of dividends reconsidered in light of corporate tax integration: proceedings of a seminar organised jointly with OECD in Toronto in 1994 during the 48th Congress of the International Fiscal Association. (pp 12-14). London (UK): Kluwer Law International.

Egger, P. \& Merlo, V. (2011). Statutory Corporate Tax Rates and Double - Taxation Treaties as Determinants of Multinational Firm Activity. FinanzArchiv, 67 (2), 145-170.

Fiszer, J. (1990). Międzynarodowe podwójne opodatkowanie (problemy definicji) [International Double Taxation (Definition Issues)]. Państwo i Prawo, 3, 75-76.

Froud, J., Haslam, C., Johal, S. \& Williams, K. (2000). Shareholder Value and Financialization Consultancy Promises, Management Moves. Economy and Society, 29, 1255-1271.

Fuest, C. \& Hemmelgarn, T. (2005). Corporate Tax policy, foreign firm ownership and thin capitalization. Regional Science and Urban Economics, 35 (5), 508-526.

Gajewski, D. (2004). Opodatkowanie grup kapitałowych $i$ holdingów [Taxation of Groups of Companies and
Holdings]. Warszawa: Wydawnictwo Zakamycze. Gajl, N. (1992) Teorie podatkowe w świecie [World's Tax Theories]. Warszawa: PWN.

Głuchowski, J. (1983). Międzynarodowe umowy wsprawiezapobieganiapodwójnemuopodatkowaniu [International Agreements on Preventing Double Taxation]. Państwo i Prawo, 2, 59.

Gomułowicz, A. \& Małecki, J. (2002). Podatki i prawo podatkowe [Taxes and Tax Law]. Warszawa: LexisNexis.

Hamaekers, H., Holmes, K., Głuchowski, J., Kordach, T. \& Nykiel, W. (2006). Wprowadzenie do międzynarodowego prawa podatkowego [Introduction to International Tax Law]. Warszawa: Lexis Nexis.

Hayder, R. (2000). Polskie unormowania w zakresie niedostatecznej kapitalizacji [Provisions of the Polish Law Concerning Thin Capitalisation]. Kwartalnik Prawa Podatkowego, 1/2, 41-42.

Helminen, M. (1999). The Dividend Concept in International Tax Law. London (UK): Kluwer Law International.

Komar, A. (1996). Systemy podatkowe krajów Unii Europejskiej [Tax Systems in European Union Member Countries]. Warszawa: PWE.

Laconick, W. \& O'Sullivan, M. (2000). Maximizing Shareholder Value, A New Ideology for Corporate Governance. Economy and Society, 29, 978-992.

Lipowski, T. (1999). Umowy o unikaniu podwójnego opodatkowania [Agreements on Avoiding Double Taxation]. Sopot: Wydawnictwo Prawnicze LEX.

Litwińczuk, H. (2003). Prawo podatkowe przedsiębiorców [Tax Law for Entrepreneurs]. Warszawa: KiK.

Niels, J. (2010). Imperfect tax competition for profits, asymmetric equilibrium and beneficial taxhavens. Journal of International Economics, 81 (2), 253-264. OECD (1992). Model Tax Convention on Income and Capital. Report of the Committee on Fiscal Affairs. Commentary on Article 10. Paris: OECD..

Overesch, M. \& Wamser, G. (2010). Corporate tax planning and thin-capitalization rules: evidence from a quasi-experiment. Applied Economics, 42 (5), 563-573.

Palpaceur, F. (2008). Bringing the Social Contex Back In: Governance and Wealth Distribution in Global Commodity Chains. Economy and Society, 37 (3), 393-419. 
Portner, R. (1996). Thin Capitalization and Tax Treaties, Unlimited Right to Tax Dividends and Interest at Source. European Taxation, 8, 266-268.

Poterba, J. M. (2004). Taxation and Corporate Payout Policy. American Economic Review, 4, 541-559.

OECD (1987). Report on „Thin Capitalization”. Issues in International Taxation, 2, 34.

Sasseville, J. (1995). Article 10 of the OECD Model Tax Convention and Different Approaches to Integration. In: International taxation of dividends reconsidered in light of corporate tax integration:proceedings of a seminar organised jointly with OECD in Toronto in 1994 during the 48th Congress of the International Fiscal Association. London (UK): Kluwer Law International.

Sieker, K. (1997). Germany: Thin Capitalization and Transfer Pricing. International Transfer Pricing Journal, 4 (4), 222.

Valchy, J. (2008). Investigating a Thin-Capitalization Rule: an option-based analysis. Politicka Ekonomie, 56 (5), 656-668.

Vogel, K. (1997). Klaus Vogel on Double Taxation Conventions, Third Edition, A Commentary on the OECD, UN, US Model Conventions for the Avoidance of Double Taxation of Income and Capital with Particular Reference to German Treaty Practice..London: Kluwer Law International.

Wells, A. (1993). Current Developments with Thin

Capitalization. The Tax Journal, 3, 9. 
